\title{
MAN'S VIEW TOWARDS VIOLENCE AGAINST WOMEN
}

\author{
ERKEĞiN KADINA YÖNELIK ŞIDDETE BAKIŞI VE TUTUMU
}

\begin{abstract}
${ }^{1}$ Ahi Evran Üniversitesi Sağlık Yüksekokulu, ${ }^{2}$ Nevşehir Üniversitesi Semra Ve Vefa Küçük Sağlık Yüksekokulu
\end{abstract}

A Gökçe DEMiR ${ }^{1}$ Gizem Deniz BULUCU ${ }^{1}$ Ayşegül ÖZCAN²

Yazıșma Adresi: Yard. Doç. Dr. Gökçe Demir Ahi Evran Üniversitesi 40100 Kırşehir - Türkiye

Eposta: gokce_demir@mynet.com

Kabul Tarihi: 06 Eylül 2013

Balıkesir Sağlık Bilimleri Dergisi

ISSN: 2146-9601

e-ISSN: 2147-2238

bsbd@balikesir.edu.tr www.bau-sbdergisi.com

\section{ÖZET} uygulanmasıdır. uygulanmıştır. Verilerin analizinde yüzdelik kullanılmıştır. $\% 42,9^{\prime}$ unun fiziksel şiddeti bildiği belirlenmiştir.
GiRiş: Kadına yönelik şiddet türlerinin en sık görülen şekli, eşler ve partnerler tarafından şiddet

MATERYAL VE METOD: Bu çalışma, Erkeğin kadına yönelik şiddete bakışını belirlemek amacıyla tanımlayıcı olarak yapıımıştır. Araştırmanın evrenini, Türkiye'nin İç Anadolu Bölgesinde bulunan Kırşehir ili Bağbaşı Mahallesi'nde yaşayan 133 evli erkek oluşturmuştur. Evrenin tümü örnekleme alınmıştır. Veri toplama aracı olarak, literatürden yararlanılarak araştırmacılar tarafından oluşturulan soru formu kullanılmıştır. Soru formları erkeklerle yüz yüze görüşerek

BULGULAR: Çalışma kapsamına alınan erkeklerin yaş ortalamasının $39.12 \pm 11.12$ olduğu saptanmıştır. Erkeklerin \%40,6'sının eşlerine şiddet uyguladığı ve kadına şiddetin evliliğin ilk yıllarında \%33,1 başladığı belirlenmiştir. Erkeklere göre şiddet nedenleri değerlendirildiğinde, $\% 12,8^{\prime} \mathrm{i}$ sinirlilik olarak görmektedir. Erkeklerin çoğunun $(\% 97,7)$ şiddet konusunda eğitim almadıkları belirlenmiştir. Erkeklerin şiddet türlerini bilme durumu değerlendirildiğinde ise

SONUÇ VE ÖNERILER: Çalışma sonucunda; erkeklerin önemli bir kısmının kadınlara şiddet uyguladığı, erkeklerin şiddeti daha çok fiziksel şiddet olarak değerlendikleri ve yine çoğunun ise şiddet konusunda herhangi bir bilgi almadıkları ve bilgilerinin olmadığı sonucuna varılmıştır. Erkeklerin şiddetin türleri konusunda eğitim yolu ile bilinçlendirilmesi önerilmektedir.

Anahtar Kelimeler: Şiddet, Kadına yönelik şiddet, Erkek

\section{SUMMARY}

OBJECTIVE: The most common forms of violence against women is engaging in violence by spouses and partners.

MATERIAL AND METHOD: This study was carried out as a descriptive for determine the man's view of violence against women. The population of there search constitudes 133 married men who live Bağbaşı neighborhood of Kırşehir, in Central Anatolia Region of Turkey. All of thepopulation have been sampled. As a means of data collection, a questionnare was used prepared by the researchers benefitting from literature. Questionnare sapplied by meeting men face to face. Percentile was used in analyzing of the data.

FiNDINGS: It is determined that average age of the men included in the study is $39.12 \pm 11.12$. It is indicated that $40,6 \%$ of men perpetrate violence to their wive sand violence against women started $33,1 \%$ during the first years of marriage. When the causes of violence considered for men, $12,8 \%$ is seen as nervousness. It is defined that most of the men $(97,7 \%)$ have not raining on violence. When the knowledge of men about types of violence considered, $42,9 \%$ of them are aware of physical knowledge.

CONCLUSION AND RECOMMENDATIONS: In the result of this study, it is concluded that a significant portion of men being violent against women, men consider violence mostly as physical violence, and stil have not receive dany information about the violence, and have noinformation. It is recomended that men should be made concious about the types of violence through education.

Key words: Violence, violence against women, man. 


\section{INTRODUCTION}

Violence against women is an important problem of society in developed and developing countries. ${ }^{1,2}$ Acording to there port which was published in 2002, it was announced that violence is mostly directed to women and generally at home. Violence is described as any kind of behaviour that depends on gender, hurts them, gives them harm, has the possible physical, sexual or psychological results, forces them in society or in their private life and restricts their freedom. ${ }^{3}$ In one sense, in the story of violence which means physical and psychological supress, generally man performs the violence and woman is exposed to it. ${ }^{4}$

Violence can be phsical, emotional, sexual or economical. Physical violence causing physical injures by beating, throwing or kicking; emotional violence is jeering and despising by verbal assaults or threats; sexual violence, forcing the person for sexual activity; economical violence, abusing the right sand mis using the money or goods. $^{5-10}$

In the society based research which was carried out in 48 country by WHO in 2002, it has been announced that 10 $69 \%$ of women expose physical violence at least one time during their life. ${ }^{3}$ It has been expressed that in developing countries, more than $50 \%$ of the women are exposed physical violence by their spouse or partners. This rate is in India 45\%, in Philippines $47.2 \%$, in Kenya $52 \% .^{8}$ In our country, the study carried out with married people between the ages of $15-49$, shows that $47 \%$ of women expose to violence and they are exopsed by their spouses. Similarly,Nwhen it comes the prevalence of spouse violence in adult women, it has been announced that the rate of women exposing to violence is $61.4 \% .{ }^{6}$ In a research carried out in Canakkale, it is stated that among the emotional violence behaviours for women, disapproval of their did; among the economical violence behaviours, not give permission to work outside; among the sexual violence, extreme jealousy comes first.As it is known violence to women performed by men who they meet, know and trust rather than stranger, unknown ones. $^{7}$

In society where traditional values are common, it is supported that men have the right to punish their wives phsically, so violence is legitimated there. Efficiency in legal regulations for domestic violence and lack of reliable, serious support systems for women contributes to increase of violence. Long run solutions in society require the participation and collaboration of both women and men. However, there isn't enough study for raising awareness and stating the roles and duties of men to struggle violence. ${ }^{5,9}$ To mention a topic as a problem, to state its importance, to awake the local government, first it is needed to describe the problem and its factors. Therefore, there search was carried out to determine the men' outlook on violence to women.

\section{MATERIAL AND METHOD}

This research was carried out to determine the men outlook on violence to women as definer. The man, who lives in Bagbası, Kırsehir, has 133 marriage is constructed the world of the research. The whole research has been expressed by samples. For gathering data, a questionary form, which was prepared by researchers who benefitted upon books and articles, has been used. In questionary form gives place to the questions that aimed at characteristic of men and their attitude toward the violence to women. For the validity of questionary form, pre-practise has been done on 10 men. We haven't changed anything on questionary form. Questionnaries were prepared by interviewing with men face to face.

Evaluating the datas: Percentage, average and chi-square tests have been made in SPSS 16.0 packet programme. $p<0.05$ has been accepted as relevance level.

\section{FINDINGS}

The demographic dispersion of 133 men taken to the study is on Table-1. It has been revealed that the average age of men is $39.12 \pm 11.12,50.4 \%$ of men graduated from primary school, $9.8 \%$ do not work, $10.5 \%$ has no health insurance and $65.4 \%$ have average or bad income level. When it comes to men' marriage characteristic and habits (Table-2), it is obvious that $24.8 \%$ of men' perception is love and respect, $21.1 \%$ is love, reliance, wish of having a child and steady life $20.3 \%$ steady life, $13.5 \%$ reliance, $10.5 \%$ wish of having a child, $9.8 \%$ love, steady life and wish of having a child and it is clear that most of the spouses (68.4\%) have a good perception of relationship.

It has been stated in Table-3 that, $61.7 \%$ of men have smoking habit, $18.0 \%$ use alchol and $38.3 \%$ go to coffee house regularly. It has been stated that $40.6 \%$ of men use violence against their wives and it starts at the first years 
Table 1. Socio-demographic Characteristics of the Man'

\begin{tabular}{|c|c|c|c|}
\hline $\begin{array}{l}\text { Sociodemographic } \\
\text { characteristics }\end{array}$ & Number & $\%$ & $X \pm S D$ \\
\hline Age & & & $39.12 \pm 11.12$ \\
\hline \multicolumn{4}{|l|}{ Education } \\
\hline Illiterate & 12 & 9.0 & \\
\hline Primary school & 67 & 50.4 & \\
\hline High school and more & 54 & 40.6 & \\
\hline \multicolumn{4}{|l|}{ Job } \\
\hline Working & 120 & 90.2 & \\
\hline Not working & 13 & 9.8 & \\
\hline \multicolumn{4}{|l|}{ Mother's Education } \\
\hline Illiterate & 81 & 60.9 & \\
\hline Primary school & 47 & 35.3 & \\
\hline High school and more & 5 & 3.8 & \\
\hline \multicolumn{4}{|l|}{ Father's Education } \\
\hline Lliterate & 49 & 36.8 & \\
\hline Primary school & 68 & 51.1 & \\
\hline High school and more & 16 & 12.0 & \\
\hline \multicolumn{4}{|l|}{ Social insurance } \\
\hline Available & 119 & 89.5 & \\
\hline Not available & 14 & 10.5 & \\
\hline \multicolumn{4}{|l|}{ İncome } \\
\hline Well & 46 & 34.6 & \\
\hline Average/bad & 87 & 65.4 & \\
\hline
\end{tabular}

of marriage (33.1\%). When the reasons of violence for men, $12.8 \%$ of men think nervosity, $17.3 \%$ jealousy, nervosity, conflict and cannot being together, 3.8\% jealousy and have no reason $3.0 \%$ the conflict between the couples is the reason why they use violence. Most of the men $(97.7 \%)$ have no education about violence, the men $(2.3 \%)$, who got educated, have acquired it via internet, media, books, magazines and health institutions or health personnels.

When the knowledge of the men about violence situation assessed (Table-3) $42.9 \%$ of them know physical violence, $26.3 \%$ phsical, verbal, $10.5 \%$ physical, verbal, sexual, emotinal $8.3 \%$ physical, verbal, sexual violence.
Table 2. Dispersion of men up to their marrage charecteristics and habits

\begin{tabular}{llc}
\hline & Number & $\%$ \\
\hline \multicolumn{4}{l}{ Sense of benefits from the marriage } & & \\
\hline Love-respect & 33 & 24.8 \\
\hline Love-reliance-having a child-an orderly life & 28 & 21.1 \\
\hline Orderly life & 27 & 20.3 \\
\hline Reliance & 18 & 13.5 \\
\hline Having a child & 14 & 10.5 \\
\hline Love -having a child- orderly life & 13 & 9.8 \\
\hline Sense of relationship between the couples & & \\
\hline Well & 91 & 68.4 \\
\hline Average/bad & 42 & 31.6 \\
\hline Smoking & & \\
\hline Yes & 82 & 61.7 \\
\hline No & 51 & 38.3 \\
\hline Alchol & & \\
\hline Yes & & \\
\hline No & & \\
\hline Coffeehouse & 109 & 82.0 \\
\hline Yes & & \\
\hline No & & \\
\hline
\end{tabular}

It has been found that perception of relationship between couples $(p=0,000)$, smoking $(p=0.005)$, going to coffeehouse $(p=0,000)$ are effective in situation of using violence; however jobs $(p=0,668)$, incomes $(p=0,904)$, using alchol $(p=0.135)$ are not effective (Table-4).

\section{DISCUSSION}

According to study results $40.6 \%$ of men using violence and women are exposed to violence mostly during the first years of their marriage (33.1\%). With the study which was done in 4287 houses throughout Turkey both in rural and urban areas, we have seen that there is physical violence in $34 \%$ of families and verbal violence inmore than $54 \%$ of families. ${ }^{11}$ Also in a study done in Çanakkale, it has been seen that $80.9 \%$ of women exposed at least one type of violence, in Edirne 61.4\%, in Sivas $40.7 \%$, in Bolu $50.9 \%$. It is obvious that the rate is high throughout Turkey, in different cities and in our study. We have witnessed that women are exposed to violence more in societies where people think that men are more important than women. ${ }^{12}$ 
Table 3. Dispersion of men up to using violence, reasons and their knowledge

\begin{tabular}{lll}
\hline & Number & $\%$ \\
\hline Characteristic of using violence & & \\
\hline Yes & 54 & 40.6 \\
\hline No & 79 & 59.4 \\
\hline
\end{tabular}

Starting point of violence in marriage $(n=54)$

\begin{tabular}{|c|c|c|}
\hline The first years of marriage & 44 & 33.1 \\
\hline After giving birth & 10 & 7.5 \\
\hline \multicolumn{3}{|l|}{ Reasons of violence $(n=54)$} \\
\hline $\begin{array}{l}\text { Jealousy, nervosity, conflict,cannot } \\
\text { together }\end{array}$ & 23 & 17.3 \\
\hline Nervosity & 17 & 12.8 \\
\hline Jealousy & 5 & 3.8 \\
\hline Having no reason & 5 & 3.8 \\
\hline Conflicts between the couples & 4 & 3.0 \\
\hline \multicolumn{3}{|l|}{ Receiving education about the violence } \\
\hline Yes & 3 & 2.3 \\
\hline No & 130 & 97.7 \\
\hline \multicolumn{3}{|l|}{ Sources of education $(n=3)$} \\
\hline Health institutions/personnels & 2 & 1.5 \\
\hline İnternet/Media/book/magazine & 1 & 0.8 \\
\hline \multicolumn{3}{|l|}{ Awaring of the violence types } \\
\hline Physical & 57 & 42.9 \\
\hline Physical,verbal & 35 & 26.3 \\
\hline I don't know & 16 & 12.0 \\
\hline Physical,sexual,verbal,emotional & 14 & 10.5 \\
\hline Physical,verbal,sexual & 11 & 8.3 \\
\hline
\end{tabular}

The patriarchal family, which is dominant in Turkey, have effected the roles of women in society in spite of the political or social reforms which was regulated from past to today. In our country, supposing the violence as a mean for punishment causes to increase in violence rate and to legitimate it both in home and public. ${ }^{13}$

When it comes to why men use violence, $17.3 \%$ of reasons are jealousy, nervosity, conflicts and cannot being together, it is really challenging finding that sometimes men have no reason to use violence.

In Sahin and his friends' ${ }^{6}$ study, according to women the reason why they exposed to violence is $21.8 \%$ disrespect, $17.2 \%$ jealousy, $1.6 \%$ sexual problems.18.7\% of women state that even unimportant daily problems cause the violence. It has been noticed that findings are similar.
Table 4. Dispersion of men up to some of their characteristics about using violence

\begin{tabular}{|c|c|c|c|c|c|c|}
\hline \multirow[b]{3}{*}{ Factors } & \multicolumn{4}{|c|}{ Using Violence } & \multirow{3}{*}{ X2test } & \multirow{3}{*}{$\mathbf{p}$} \\
\hline & \multicolumn{2}{|c|}{ Yes } & \multicolumn{2}{|c|}{ No } & & \\
\hline & $n$ & $\%$ & $n$ & $\%$ & & \\
\hline \multicolumn{7}{|l|}{ Having a job } \\
\hline Working & 48 & 40.0 & 72 & 60.0 & & \\
\hline Not working & 6 & 46.2 & 7 & 53.8 & 0.184 & 0.668 \\
\hline
\end{tabular}

Assesing the incomes

\begin{tabular}{l|l|l|l|l|ll}
\hline Well & 19 & 41.3 & 27 & 58.7 & & \\
\cline { 1 - 5 } Average/bad & 35 & 40.2 & 52 & 59.8 & 0.014 & 0.904 \\
\hline
\end{tabular}

Sense of relationship between the couples

\begin{tabular}{l|c|c|c|c|cc}
\hline Well & 24 & 26.4 & 67 & 73.6 & & \\
\cline { 1 - 4 } Average /bad & 30 & 71.4 & 12 & 28.6 & 24.188 & .000 \\
\hline
\end{tabular}

Smoking

\begin{tabular}{l|l|l|l|l|ll}
\hline Yes & 41 & 50.0 & 41 & 50.0 & & \\
\cline { 1 - 5 } No & 13 & 25.5 & 38 & 74.5 & 7.832 & .005 \\
\hline
\end{tabular}

Alchol

\begin{tabular}{l|l|l|l|l|ll}
\hline Yes & 13 & 54.2 & 11 & 45.8 & & \\
\cline { 1 - 5 } No & 41 & 37.6 & 68 & 62.4 & 2.234 & 0.135 \\
\hline
\end{tabular}

Coffehouse

\begin{tabular}{l|l|l|l|l|ll}
\hline Yes & 31 & 60.8 & 20 & 39.2 & & \\
\cline { 1 - 5 } No & 23 & 28.0 & 59 & 72.0 & 13.972 & .000 \\
\hline
\end{tabular}

In structure of patriarcal family in Turkish people, women have no right to speak; therefore it is usual to admit the men saying as an order and being punished in case of disobedience. As social structure, Turkish women have seen violence as a result of neglecting the rules and disobedince. So, they find themselves guilty because of the violence they exposed ${ }^{8}$

In our study, it has been found that $33.1 \%$ of the men use the violence for the first timeduring the first years of marriage. This result is compatible with the other studies in Turkey and in other countries. ${ }^{6,17}$ It is supposed that communication is a common problem during the first years of marriage and it is a risky factor for violence. ${ }^{6}$

Most of the men, who participated the study, has not been educated (97.7\%) and half of them know physical violence as a violence type. Awaring only this type of violence causes not realize the other type of violence even if they use. Moreover, this situation causes the improvement of physical violence. 
Sense of the relationship between couples $(p=0.000)$ for men has an effect on the level of using violence. The study of Gage and his friends which includes 2564 women, shows that a high quality communication is preservative against physical, verbal or sexual violence. It is more common seeing the violence in familiess who always has quarrel, who has bad communication, who cannot move or decide collaborately. ${ }^{18,19}$

By examining the story of poor and divorced women, it has been seen that they $(42.86 \%)$ often expoed to beating during their marriage. ${ }^{15}$ According to literature, men who has no job or no regular job use violence more. ${ }^{3,8}$ In the study of Yaman Efe and Ayaz, ${ }^{8}$ it is clear that women whose husband does not work and have bad income exposed to violence more. In a field study which was done in Vietnam by Vung and his friends, ${ }^{16}$ it has been seen that men who work in unqualified job use violence more than (2.6\%) the men working in qualified job. In our study, the jobs ( $p=0.668)$, incomes $(p=0.904)$ has no effect on using violence; in this respect it is different from the literature.

Many studies have shown the positive relation between the alchol and using physical violence. ${ }^{14,19,20}$ In Sahin's ${ }^{6}$ study, women have described the alchol as the first reason. However this finding $(p=0.135)$ is not compatible with literature and it has been found that alchol has no effect on using violence. It has been found in our study that smoking and coffeehouse habit has an effect on violence. In Donmez's study, ${ }^{21}$ it is obvious that men who smoke, use physical and economical violence more.

A spare time activity, going to coffeehouse has an important effect on Turkish socity's daily life. Especially unemployed people, artisans, people who want to chat go to coffeehouse; however as the time passed women have started to think this situation as a cause for violence. $^{22}$

\section{CONCLUSION AND SUGGESTIONS}

Acording to study results $40.6 \%$ of men using violence and women are exposed to violence mostly during the first years of their marriage (33.1\%). It has been stated as a challenging finding that sometimes men have no reason to use violence. Sense of relationship between the couples for men, it has been found that smoking and coffeehouse habit has an effect but jobs, income and alchol has no effect on sing violence.
In the direction of these results;

The role and responsibility given men should be a lot, Men should be educated,

The more study should be done to make men aware of the situation.

\section{REFERENCES}

1. Watts C, Zimmerman C. Violence against women: global scope and magnitude. Lancet 2002;359:1232-7.

2. Heise $L L$, Raikes $\mathrm{A}$, Watts $\mathrm{CH}$, et al. Violence against women: $\mathrm{A}$ neglected public health issue in less developed countries. Soc Sci. Med 1994;39(9):1165-79.

3. Krug E, Dahlberg L, MercyJ, Zwi A, Lozano R. World Health Organization. World Report on Violence and Health: Summary.Geneva, 2002.

4. Gökkaya VB. Economical violence against the women in Turkey. C.Ü. Economics and Administrative Science Journal 2011; 12(2):101-112.

5. Güler T, Tel H, Tuncay FÖ. Women view to the violence in family. C.Ü. Medicine Faculty Journal 2005; 27(2): 51-56.

6. Şahin EM, Yetim D, Öyekçin DG. Prevalence of husband violence against women and women attitudes in Edirne. Cumhuriyet Medicine Journal 2012; 34:23-32.

7. Pınar G, Pınar T. The view of university students about the violence against women. Health and Society. 2007; 17(2):76-83.

8. Yaman Efe Ş, Ayaz S. Violence against women and their view . Anatolian Journal of Psychiatry 2010; 11:23-29.

9. Ulutaşdemir N. Violence against women. Health and Society 2002; 12(4):15-20.

10. Tanrıverdi G, Şıpkın S. In Çanakkale, educational level of the women who Consult Health Center. Firat Medicine Journal 2008 13(3):183-187.

11. T.C.Presidency of Family Research Association(2000). The Reasons and Results of Violence in Family. Ankara.

12. Fikree F.F, Razzak J.A, Durocher j. Attitudes of Pakistani men to domestic violence: a study from Karachi, Pakistan. JHMG 2005; 2(1):49-58

13. Page A.Z, Ince M. A Compilation about the violence in family Turkish Psychology Essays 2008; 11 (22): 81-94.

14. Gage AJ, Hutchinson PL. Power, control, and intimate partner sexual violence in Haiti. Arch Sex Behav. 2006;35(1):11-24

15. Arıkan Ç. Poverty, Lack of Harmony, Divorce. Ankara: şafak Printery (page AZ)

16. Vung ND, Ostergren PO, Krantz G. Intimate partner violence against women in rural Vietnam: different socio-demographic factors are associated with different forms of violence. Need for new intervention guidelines? BMC Public Health. 2008; 8(1):55

17. Ellsberg MC, Peña R, Herrera A, Liljestrand J, Winkvist A.Wife abuse among women of childbearing age in Nicaragua. Am J Public Health 1999; 89:241-4.

18. Choi SY, Ting KF. Wife beating in South Africa: an imbalance theory of resources and power. J Interpers Violence. 2008, 23(6):834-52. 
19. Parish WL, Wang T, Laumann EO, Pan S, Luo Y. Intimate partner violence in China: national prevalence, risk factors and associated health problems. Int Fam Plan Perspect. 2004;30(4):174-81.

20. Peek Asa C, Zwerling C, Young T, Stromquist AM, Burmeister LF, Merchant JA. A population based study of reporting patterns and characteristics of men who abuse their female partners. Inj Prev. 2005; 11(3):180-5.

21. Dönmez G. Determing The Existence of Violence and its Types and Factors Among the Married Men.izmir, Dokuz Eylül University, Medicine Faculty Society Health Department Branch Thesis, 2008.

22. Yağbasan $M$, Ustakara $F$. The study of determining the communication in coffeehouse in Turkish Society (Example of Gaziantep). Firat University Social Science Journal 2008; 18(1):233-260. 